\title{
FOREIGN INTERVENTION IN AFRICA: FROM THE COLD WAR TO THE WAR ON
}

\section{Elizabeth Schmidt}

Stanford, New York: Cambridge University Press

2013

Pages 267

ISBN 9780521709031

This book by Elizabeth Schmidt, Professor of History at Loyola University Maryland, was published in the series New Approaches to Africa History, designed to introduce students to current findings and new ideas on the history of the continent. This approach affected the mode of presentation, but did not prevent the book from being a profound and pioneering academic work.

The foreword to the book was written by William Minter, a renowned Africanist, who in particular expresses a sobering if somewhat unexpected thought, "In the context of the second decade of the twenty-first century, the danger of too much intervention or bungled intervention seems more likely than the danger of no intervention at all" (p. xvi).

The structure of the book is quite logical. The Introduction is followed by the first chapter, where Schmidt provides an analysis of nationalism and decolonisation during the Cold War (1945-1991). The introduction examines the ideologies, interests and practices of external powers involved in Africa. Schmidt divides them into Imperial actors, namely former metropoles and Cold War actors. She correctly states that during the Cold War period, the USA and USSR "offered two very different development models" and in the eyes of Third World leaders, while "development according to the American model would take far too long", the Soviet Union "provided an attractive alternative" (p. 26). Besides, Africa did not associate Moscow "with exploitive European colonialism" while Washington with inherent links to other Western countries had "its own history" of interference in Latin America and Indo-China (p. 27). It should be emphasised that Schmidt does

Scientia Militaria, South African Journal of Military Studies, Vol 42, Nr 1, 2014, pp. 133-135. doi : $10.5787 / 42-1-1085$ not reduce the Cold War to American-Soviet confrontation, and writes about a third important actor, namely the People's Republic of China as well as a fourth one, Cuba, which had "an emotional link to Africa" (p. 29). 
The next five chapters can be regarded as case studies, covering main areas of armed conflicts in Africa: North Africa and in particular Egypt and Algeria, the former Belgian Congo, the Portuguese colonies, Southern Africa and the Horn of Africa. Chapter 7 analyses French intervention in various parts of its former colonial empire.

Chapter 8 as concluding piece entitled, "From the Cold War to the War on Terror, 1991-2010" is devoted to foreign intervention in Africa during the past two decades. It contains in particular a remarkable insight,

The George W. Bush administration's "global war on terror" became the new anticommunism. Just as domestic insurgencies sparked by local grievances were mistaken for "communist aggression" during the Cold War, the vague rubric of "international terrorism" was used to explain a range of civil disturbances in the early twenty-first century (p. 213).

Each chapter contains "Suggested Reading", comprising a selection of sources for further studies and to strengthen insights on the particular theme.

The book is a product of meticulous research and deep reflection. In particular, it is a distinct work compared to many others published in the West, and provides succinctly a realistic assessment of the Soviet policy in Africa. For example, Schmidt quite correctly writes,

Lumumba's assassination was a blow to the Soviet Union. However, it did not harm Soviet prestige in Africa and Asia. On the contrary, having supported Lumumba and his cause more than any other nonAfrican power, the Soviet Union emerged from the 1960 crisis with (the increased) respect of many nonaligned nations. The United States, in contrast, found its reputation badly damaged (p. 65).

This is not to say that Schmidt's narrative is free from deficiencies. In several cases, the data given by the author are not substantiated by any reference. Thus, she writes that Moscow "contributed twenty-six planes and six helicopters" (p. 61) to the UN operation in the Congo, but the number of planes is grossly overestimated, and no helicopters were provided. Besides, the planes were put at the disposal of Lumumba's government. Also unsubstantiated is her claim that Sawaba's guerrillas from Niger "were trained and equipped by the Soviet Union" (p. 182). Schmidt also states that Moscow provided some twenty thousand advisors "to Egypt after the Six-Day War (p. 44), but by President Nasser's request, apart 
from advisors, it dispatched combat units as well, notably an Anti-Aircraft Missile Division". Again this statement is unsubstantiated.

In the reviewer's opinion, the most deplorable fault of the book is the lack of critical analysis of the developments in Cote d'Ivoire and especially Libya in 2011. In the first case, Schmidt correctly writes, "UN and French forces conducted military strikes against government strongholds", but does not mention that the Security Council's resolution (Resolution 1973) did not provide for such actions. In the second case, she wrongly claims that NATO "air strikes against government tanks and artillery" were UN-approved and that "foreign intervention was justified on the ground of protecting civilian lives" (p. 195), forgetting that these strikes, on the contrary, caused the death of thousands of civilians.

In the Conclusion of the book, Schmidt states, "during the period under consideration (1945-2010), foreign intervention in Africa generally did more harm than good" (p. 229). Generally - maybe, but there are cases when such intervention was fully justified, for example, in support of the anti-colonial and anti-apartheid struggle.

Critical comments notwithstanding, Schmidt's book can be strongly recommended to readers, especially to scholars of African history and international relations.

Vladimir Shubin, Institute for African Studies, Russian Academy of Sciences (vlgs@yandex.ru) 